(C) NIAB 2015. This is an Open Access article, distributed Plant Genetic Resources: Characterization and Utilization (2017) 15(1); 51-63 under the terms of the Creative Commons Attribution licence (http://creativecommons.org/licenses/by/4.0/), which permits unrestricted re-use,

distribution, and reproduction in any medium, provided the original work is properly cited.

ISSN 1479-2621

\title{
Longitudinal analysis of maize diversity in Yucatan, Mexico: influence of agro-ecological factors on landraces conservation and modern variety introduction
}

\author{
Marianna Fenzi ${ }^{1}$, Devra I. Jarvis ${ }^{2 *}$, Luis Manuel Arias Reyes ${ }^{3}$, \\ Luis Latournerie Moreno ${ }^{4}$ and John Tuxill ${ }^{5}$ \\ ${ }^{1}$ Centre Alexandre-Koyré - École des hautes études en sciences sociales (EHESS), \\ Paris, France, ${ }^{2}$ Bioversity International, Maccarese, Rome Italy, ${ }^{3}$ CINVESTAV-IPN \\ Unidad Mérida, Merida, Yucatan, Mexico, ${ }^{4}$ Instituto Tecnológico de Conkal, \\ Division de Estudios de Posgrado e Investigación, Conkal, Yucatan, Mexico and \\ ${ }^{5}$ Fairhaven College of Interdisciplinary Studies, Western Washington University, \\ Bellingham, WA, USA
}

Received 15 December 2014; Revised 10 April 2015; Accepted 3 July 2015 - First published online 2 September 2015

\begin{abstract}
Transformations that farmers bring to their traditional farming systems and their impacts on the conservation and evolution of maize varieties over a 12-year period are investigated using a longitudinal analysis. Despite the increased introduction and supply of improved maize variety seeds in the Yucatan Peninsula, Mexico, over the last 12 years farmers continue to maintain a substantial amount of traditional maize variety diversity. Even with the increased availability of hybrid seeds, farmers in the community of Yaxcaba on average plant more than three quarters of their milpa fields to traditional maize varieties, with the latter one fourth predominately planted to a locally improved variety Nal Xoy, a farm cross of a traditional variety and an improved variety. We observed a significant reduction in yellow $-x$-Nuuk nal, a long-cycle traditional landrace, paralleled by an increase in short- and intermediate-cycle locally adapted improved maize varieties. We found great differences in the distribution of maize varieties by soil type, with modern varieties being targeted for the rarer, deeper and fine-grained soils, while traditional varieties predominate on the more prevalent stony and thin soils. Our results provide a picture in which most traditional maize varieties in Yaxcaba continue to be maintained by farmers, coexisting with locally adapted improved varieties on the same landscape, and allowing the continued evolution of maize populations.
\end{abstract}

Keywords: crop evolution; crop genetic diversity; milpa; traditional varieties

\section{Introduction}

Genetic erosion linked to the loss of local crop varieties has been a major concern within scientific community

*Corresponding author. E-mail: d.jarvis@cgiar.org since the late 1960s (Frankel, 1967; Frankel and Bennett, 1970; Wilkes and Wilkes, 1972; Harlan, 1975). The 1980s and 1990s saw the launch of projects to investigate the complex association between genetic erosion and changes in traditional agriculture (Tuxill and Nabhan, 2001; Brush, 2004). The study of the replacement of indigenous crop varieties with modern ones and the idea that traditional agricultural systems are static and relatively 
isolated (Frankel, 1973) gave way to more complex studies focused on a more interconnected view of crop genetic diversity (Zimmerer, 1996; Brush, 2004; Jarvis et al., 2011; Leclerc and Coppens, 2012).

Mexico is one of the world's centres of crop diversity and contains the centre of origin of maize (Zea mays) with 62 races out of the 350 documented in all of Latin America (Kato et al., 2009). Mexico has also been a central actor in the Green Revolution, since the 1940s through the Rockefeller Foundation's programme, and the $1960 \mathrm{~s}$ through CIMMYT's maize improvement programmes (Cotter, 2003). Mexican agricultural development has created a regime of coexistence of high yielding maize seed varieties (HYV) and landraces (Ortega Paczka, 2003). Trade liberalization, launched in 1994, reinforced the role of transnational agribusiness, which supported the spread of technological packages (improved seeds, herbicides and chemical fertilizers) through subsidies or campaigns of new production models (Fox and Haight, 2010).

In the 1990s, several pioneering research projects on maize diversity management were launched in Mexico, which paved the way to a deeper understanding of 'genetic erosion' and maize diversity management strategies. However, little focus was placed on understanding how traditional crop genetic diversity is affected by the dynamics of the introduction of new technologies, in particular the technological packages, capital investment, and hired labour needed to introduce the HYV in traditional farming systems. The management of genetic resources of maize is the product of social processes (Anderson, 1946; Hernandez, 1985) and farmer perceptions of local and introduced varieties (Louette et al., 1997; Arias et al., 2000; Bellón and Hellin, 2011). These local dynamics, together with ecological restrictions, shape the traditional agricultural practices that support landrace conservation (Perales et al., 2003b; Brush and Perales, 2007).

The aim of this study is to understand what happens when modern and local varieties compete, using a longitudinal analysis based on two different surveys performed in 1999 and 2011 in the municipality of Yaxcaba, Yucatan, Mexico. Longitudinally based case studies of farmers' management of crop varieties have recently been identified as a key research priority for genetic resources conservation (Dyer et al., 2014, 2015; Brush et al., 2015). We investigate why Yaxcaba farmers have continued to plant and manage maize landraces when modern varieties and commercial maize hybrids have become widely distributed and relatively easily accessed within the community and region. We also investigate transformations that farmers bring to their traditional farming systems and their impacts on the conservation and evolution of maize varieties over a 12 -year period.

\section{Materials and methods}

\section{Study site}

The municipality of Yaxcaba is located in the central maize-growing zone of Yucatan state at $20^{\circ} 32^{\prime} 52^{\prime \prime}$ North and $88^{\circ} 49^{\prime} 40^{\prime \prime}$ West longitude, encompassing approximately $147,400 \mathrm{ha}$ and lying $108 \mathrm{~km}$ east-southeast of Merida, the principal urban centre of the Yucatan peninsula.

The region has a seasonally dry tropical climate of subtype $A w o$ with a mean annual temperature of $26^{\circ} \mathrm{C}$ and a mean annual precipitation of $1024 \mathrm{~mm}$. Temperature and altitudinal gradients are homogenous throughout the municipality of Yaxcaba. The major source of agroecological heterogeneity relates to soil differences.

Yaxcaba is in the middle of the zona maicera (maizeproducing zone) that stretches across central and eastern Yucatan state, where small-scale milpa agriculture retains an important presence on the landscape and in the local economy. Approximately 9970 ha of milpa were cultivated in 2011 in Yaxcaba municipality with a mean production of 0.69 ton/ha of maize (SIAP, 2011). The principal rainfed milpa crops in Yaxcaba are maize, beans (Phaseolus vulgaris and Phaseolus lunatus), squash (Cucurbita moschata and Cucurbita argyrosperma) and chile peppers (Capsicum annuum and Capsicum chinense). The rural population is predominantly Yucatec Maya in ethnicity and culture, and the zona maicera is considered as one of the most 'traditional' or Mayero regions of the Yucatan peninsula (Re Cruz, 1996).

Agro-morphological studies (Ortega Paczka and Dzib, 1992; Arias, 1995; Arias et al., 2002) have shown that the local maize populations planted in Yaxcaba correspond to the Mesoamerican and precolombian races Nal t'eel and Tuxpeño (known in Yucatan as $x$-Nuuk nal) and the subrace Ts'iit bakal (within the race Olotillo), which represent $75 \%$ of the maize diversity collected in the whole Yucatan Peninsula (Ortega Paczka and Dzib, 1992; Arias, 1995; Arias et al., 2002). From the data obtained in 1999 and 2000 surveys, four genetic groups have been identified in Yaxcaba municipality based on the female ear maturation time and cob characteristics. Accordingly, we followed planting trends of an early maturing group of 62-72 days (local varieties Nal t'eel, $x$-T'uup nal and $x$-Mejen nal), and a late group of 83-90 days (Ts'it bakal and $x$-Nuuk nal varieties) within the Tuxpeño race and intermediate groups. All of the above varieties occur in yellow-, white- and blue-seeded populations (or seed lots), and farmers usually do not mix seed colours within a given population. We also documented trends in creolized varieties that are based on advanced generations of hybrids and open-pollinated varieties released by regional breeding 
programmes that have been present in Yaxcaba since at least the 1980s (mejorado), and commercial varieties, mainly hybrids and a few open-pollinated varieties that have been recently (1-2 years) bought in a formal market and planted by farmers (hibrido).

\section{Data collection}

Surveys of farmers were conducted in two different periods: 1999 and 2011 in Yaxcaba during the primary growing season (April to September). Sixty-one farmers in 1999 and 71 farmers in 2011 who had milpas in Yaxcaba were sampled, corresponding to approximately $10 \%$ of ejidatarios - ejido members with usufruct rights on common land in the community. The ejido is a legal form of common lands established by Mexico's Land Reform during the 20th Century (1915-1992), in which members have usufruct rights on land that is owned by the community and managed for public benefits, primarily agriculture. Accordingly to what was reported by farmers in informal discussions during interviews, only about two hundred of the ejidatarios in Yaxcaba are actually making milpa. In addition, in 2011 more than 100 farmers not having formal ejidatario status made milpa on the ejido's lands, therefore not disposing of governmental agricultural subsidy payments. The entire area of milpa cultivated annually in the ejido is estimated at approximately $1800 \mathrm{ha}$. The sampled farmers were initially selected in 1999 through a random selection of households stratified by geographic quadrants within Yaxcaba town (Jarvis et al., 2008; Tuxill et al., 2010). Thirty farmers interviewed in 1999 were included in the same group of farmers surveyed in 2011.

\section{Interviews}

Semi-structured interviews and participant observation were carried out in 2011 based on a questionnaire derived from the 1999 survey (see online Supplementary materials for complete survey). The variables quantified in the interviews in 1999 and 2011 included: the frequency and area to which farmers planted each different varieties of maize; the size and location of each milpa planted; the agroecological conditions under which the milpa is grown (association of cultivars, soil types and duration of cultivation); number of years each variety was grown; quantity of yield obtained in the last harvest, i.e. previous year (the latter expressed both using a qualitative scale and with quantitative estimates).

To analyse information on seed flows, the concept of seed lots was used (following Louette et al., 1997) where a seed lot is an identifiable variety managed as a single unit by one farmer during a single population generation (i.e. one cropping cycle). Farmers were asked about the quantity of maize seed that they used in the previous year; where and how they obtained their seed; the frequency with which they change seeds; their seed storage strategies; and the qualities and traits they valued in their maize varieties. Information from the farmers about other varieties not currently planted but that they had grown in the previous 10 years was collected separately.

In addition to specific information about seed lots, basic demographic information was collected for each farm household interviewed. Farmers also were asked about other jobs and activities (such as beekeeping; hunting; livestock production; and local food processing, preparation and consumption) and other household income sources, including government subsidy and household support programs (e.g. PROCAMPO and DICONSA). The interviews were conducted in either the farmers' homes or at their milpas, depending on the preference of the farmer. The interviews were conducted in either Spanish or Yucatec Maya depending on the language preference of the farmer; a local interpreter assisted with Maya translations. To supplement the information gained from interviews, a subset of farmers was also visited on separate occasions to observe their milpas and other household production sites and activities. Beekeeping, for instance, is a major income-generating activity that many farm households combine with milpa in rural Yucatan.

\section{Data analysis}

Processed data were analysed by using descriptive statistics to score scale responses, frequency distributions and mean comparisons. Statistical analyses were performed using the GraphPad Prism software Inc., (La Jolla, California, USA). Total area planted to each maize variety, both local and modern, was calculated based on GPS measurements and farmers' diagrams and descriptions of their plots using the methods described in Jarvis and Campilan (2006). Standard diversity indices for crop varietal diversity (Jarvis et al., 2008), including richness (number) of maize varieties grown, and evenness estimated as a complement of $D(1-D)$, where $D$ is the Simpson measure of dominance, were calculated and transformed logarithmically $1 /(1-\mathrm{LN})$ (Magurran, 2003; Jarvis et al., 2008). Percentage divergence (i.e. the partition of diversity between and within farms) was calculated as the difference between community and farm index values divided by the community Simpson index. The average number of maize varieties per household and mean household Simpson Index was calculated for 
Table 1. Demographics and socio-economic characteristics of study participants. Median age \pm standard deviation is indicated in years. For other characteristics, numbers or percentages (in brackets) of farmers are presented

\begin{tabular}{|c|c|c|c|c|c|c|c|}
\hline Year & Number & $\begin{array}{c}\text { Median } \\
\text { age (range) }\end{array}$ & Buying maize & Selling maize & $\begin{array}{c}\text { Sons making } \\
\text { milpa }\end{array}$ & $\begin{array}{l}\text { Paying } \\
\text { for milpa }\end{array}$ & Honey \\
\hline 1999 & 61 & $54(30-86)$ & $45(63 \%)$ & $19(31 \%)$ & 35 (57\%) & $26(43 \%)$ & $18(30 \%)$ \\
\hline
\end{tabular}

the two years surveyed (1999 and 2011). The total maize variety richness was calculated by summing the number of distinct maize varieties found in Yaxcaba. Groups were compared by using a non-parametric MannWhitney $U$-test. Spearman's rank test was used to determine correlations. $P$ values above 0.05 were considered not statistically significant.

\section{Results}

\section{Demographics and socio-economic characteristics of study participants}

Demographic and socio-economic characteristics of the 61 farmers in 1999 and 71 farmers in 2011 interviewed are summarized in Table 1 . Median age of farmers increased from 54 (range 30-86) years in 1999 to 62 (range 26-90) years in $2011(P=0.0018)$ reflecting that many of the original farmers interviewed in 1999 still were included in the 2011 survey. Slightly higher proportions of farmers buying maize were observed in 2011 (76\%) compared with 1999 (63\%; $P=0.0921$ ), while we observed a reduction in the proportions of farmers selling maize from 1999 (31\%) to 2011 (14\%; $P=0.0214)$. The proportion of farmers who have sons helping them to make milpa was 57\% in 1999 and 49\% in $2011(P=0.3855)$. A slight increase was observed in the proportions of farmers paying for milpa between 1999 and 2011 ( 43 and $47 \%$ respectively; $P=0.7266$ ). Finally, the proportion of farmers producing honey as a part of their household activities was the same in 1999 (30\%) and $2011(30 \% ; P=1)$.

\section{Maize richness and evenness stability between 1999 and 2011 in Yaxcaba}

A comparison of average richness and evenness between 1999 and 2011 was performed in order to determine trends in maize varietal diversity conservation on farm. We failed to detect any significant difference in average household richness for maize between the data obtained in $1999(2.21 \pm 1.08)$ and $2011(2.42 \pm 1.24)(P=0.3588$; Fig. 1(a) left panel and Table 2) indicating that similar numbers of maize varieties were cultivated by households at both time periods. Analysis of evenness at the household level for maize revealed similar low values $(0.27 \pm 0.24$ in 1999 versus $0.33 \pm 0.25$ in 2011, $P=0.2221$; Fig. 1(a) right panel), which suggests that most farmers' fields were and still are dominated by one maize variety. When longitudinal analysis was restricted to those farmers ( $n=30$ ) who were present in both the 1999 and the 2011 surveys, a trend increasing towards richness not reaching
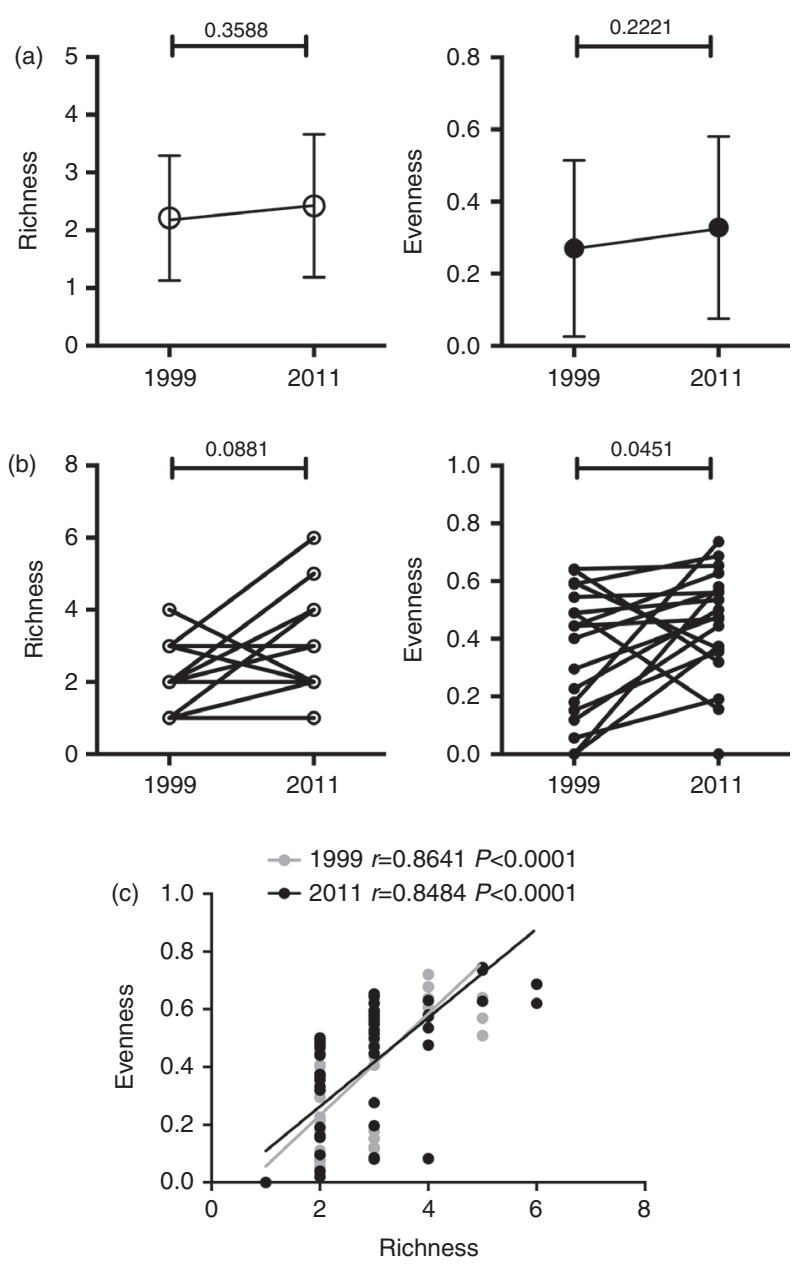

Fig. 1. Comparison of diversity estimates in 1999 and 2011 surveys. (a) Mean richness (left panel) and evenness (right panel) in 1999 and 2011. (b) Longitudinal analysis for single farmer's richness (left panel) and evenness (right panel) in 1999 and 2011. (c) Relationship between farm evenness and richness in 1999 (left panel) and 2011 (right panel). 
Table 2. Community and household area statistics and estimates of diversity for maize varieties in Yaxcaba

\begin{tabular}{|c|c|c|c|}
\hline & 1999 & 2011 & $\begin{array}{c}\text { Non-parametric } \\
\text { Mann-Whitney U-test }\end{array}$ \\
\hline Mean $\mathrm{HH}$ area planted to Maize (ha) & $3.79 \pm 1.86$ & $2.95 \pm 1.41$ & $P=0.0103$ \\
\hline $\begin{array}{l}\text { Mean } \mathrm{HH} \text { area (ha) and mean } \\
\text { percent }(\%) \mathrm{HH} \text { area planted to modern varieties }{ }^{\mathrm{a}}\end{array}$ & $0.27+0.84(7 \%)$ & $0.21 \pm 0.41(9 \%)$ & NS \\
\hline $\begin{array}{l}\text { Mean } \mathrm{HH} \text { area (ha) and percent }(\%) \\
\mathrm{HH} \text { area of locally adapted improved } \\
\text { varieties (locally bred landrace } \times \text { modern cross) }\end{array}$ & $0.33 \pm 0.90(2 \%)$ & $0.476 \pm 0.657(12 \%)$ & $P=0.0006$ \\
\hline $\begin{array}{l}\text { Mean } \mathrm{HH} \text { area (ha) and percent }(\%) \mathrm{HH} \text { area } \\
\text { planted to traditional varieties }\end{array}$ & $3.46+1.83(91 \%)$ & $2.47 \pm 1.55(79 \%)$ & $P=0.002$ \\
\hline Mean $\mathrm{HH}$ richness & $2.21 \pm 1.08$ & $2.42 \pm 1.24$ & $P=0.3588$ \\
\hline Mean HH evenness & $0.27 \pm 0.24$ & $0.33 \pm 0.25$ & $P=0.2221$ \\
\hline Community richness & 13 & 13 & $\mathrm{~N} / \mathrm{A}$ \\
\hline Number of modern varieties & 2 & 2 & $\mathrm{~N} / \mathrm{A}$ \\
\hline Number of locally adapted improved varieties & 1 & 1 & $\mathrm{~N} / \mathrm{A}$ \\
\hline Community evenness & 0.71 & 0.80 & $\mathrm{~N} / \mathrm{A}$ \\
\hline Divergence & 0.61 & 0.59 & $\mathrm{~N} / \mathrm{A}$ \\
\hline
\end{tabular}

NS, not significant.

a Modern varieties include improved (advanced generations of commercial varieties) and hybrid maize.

statistical significance $(P=0.0582)$ and a significant increase in evenness $(P=0.0451)$ were observed (Fig. 1(b)). The analysis of the relationship between the two measures of diversity, richness and evenness, at household level was highly correlated in both 1999 and 2011 (Fig. 1(c)). At the community level, the number of varieties remained the same (community richness $=13$ varieties; Table 2). Community evenness increased slightly, indicating a more even distribution of the area planted to the 13 varieties in the community of Yaxcaba in 2011 than in 1999, which can be seen in Table 2. The divergence or the difference between values of richness and evenness among households in the Yaxcaba community decreased in 2011 (Table 2).

\section{Maize variety cultivation and land use}

The mean area per household devoted to maize cultivation decreased significantly from $3.79 \pm 1.86$ ha in 1999 to $2.95 \pm 1.41$ ha in $2011(P=0.0103$; Table 2$)$. This reduction appears to result from a decrease in the cultivated area allocated to traditional varieties, from $3.46 \pm 1.83$ ha or $91 \%$ of the total household area devoted to maize in 1999 to $2.47 \pm 1.55$ ha $(79 \%)$ in 2011 ( $P=0.002$ ), while the area devoted to locally adapted improved maize varieties significantly increased from $0.33 \pm 0.90$ ha $(2 \%)$ in 1999 to $0.48 \pm 0.66$ ha $(12 \%)$ in $2011(P=0.0006)$.

To better determine the reasons for this change, we next studied the relative amount of cultivated area allocated to each maize variety in 1999 and 2011 (Fig. 2; see also online Supplementary materials). X-Nuuk nal (Tuxpeño) either Sak nal ('white maize') or K'an nal ('yellow maize') represented in 1999 the most widely cultivated varieties, covering $32.71 \pm 5.05 \%$ and $42.12 \pm 5.35 \%$ respectively of milpa surface (Fig. 2(a) and (b)). Similar proportions of white $x$-Nuuk nal cultivated areas were still planted in 2011, while a significant decrease in the proportion of milpa areas allocated to yellow $x$-Nuuk nal was observed $(25.4 \pm 4.35 \%$ in 2011; $P=0.0188$; Fig. 2(b)). When we analysed the areas cultivated with other traditional maize varieties, including - $x$-Éek' jub, white and yellow Ts'it bakal, white and yellow $x$-T'uup nal, white and yellow $x$-Mejen nal and Nal t'eel, we failed to detect any significant difference in both the area and proportions of cultivated areas between 1999 and 2011 (Fig. 2(a) and (b)). We next looked at the areas cultivated with locally adapted improved maize varieties. As shown in Fig. 2(a), no difference between 1999 and 2011 was observed in mean area cultivated with either Maiz mejorado or Maíz híbrido. In contrast, a significant increase was observed when proportions of land allocated to Maiz bibrido cultivation were analysed (from $2.63 \pm 1.08 \%$ in 1999 to $7.27 \pm 1.99 \%$ in 2011; $P=0.019$ ) (Fig. 2(b)). Interestingly, the most notable changes were observed when we considered areas allocated to the variety $\mathrm{Nal}$ Xoy, a locally adapted cross established by Rufino Chi, a Mayan farmer from the village of Xoy, between the improved maize variety PR-7822 and the traditional variety Nal t'eel. We found a significant increase in surfaces allocated to Nal Xoy cultivation from 1999, when $\mathrm{Nal}$ Xoy cultivation represented only $2.21 \pm 1.16 \%$ of the maize acreage, to 2011 when $12.27 \pm 2.98 \%$ of the maize cultivation area was constituted by Nal Xoy $(P=0.0042)$ (Fig. 2(a) and (b)). Collectively, these results show that between 1999 and 2011 a decrease in the areas 

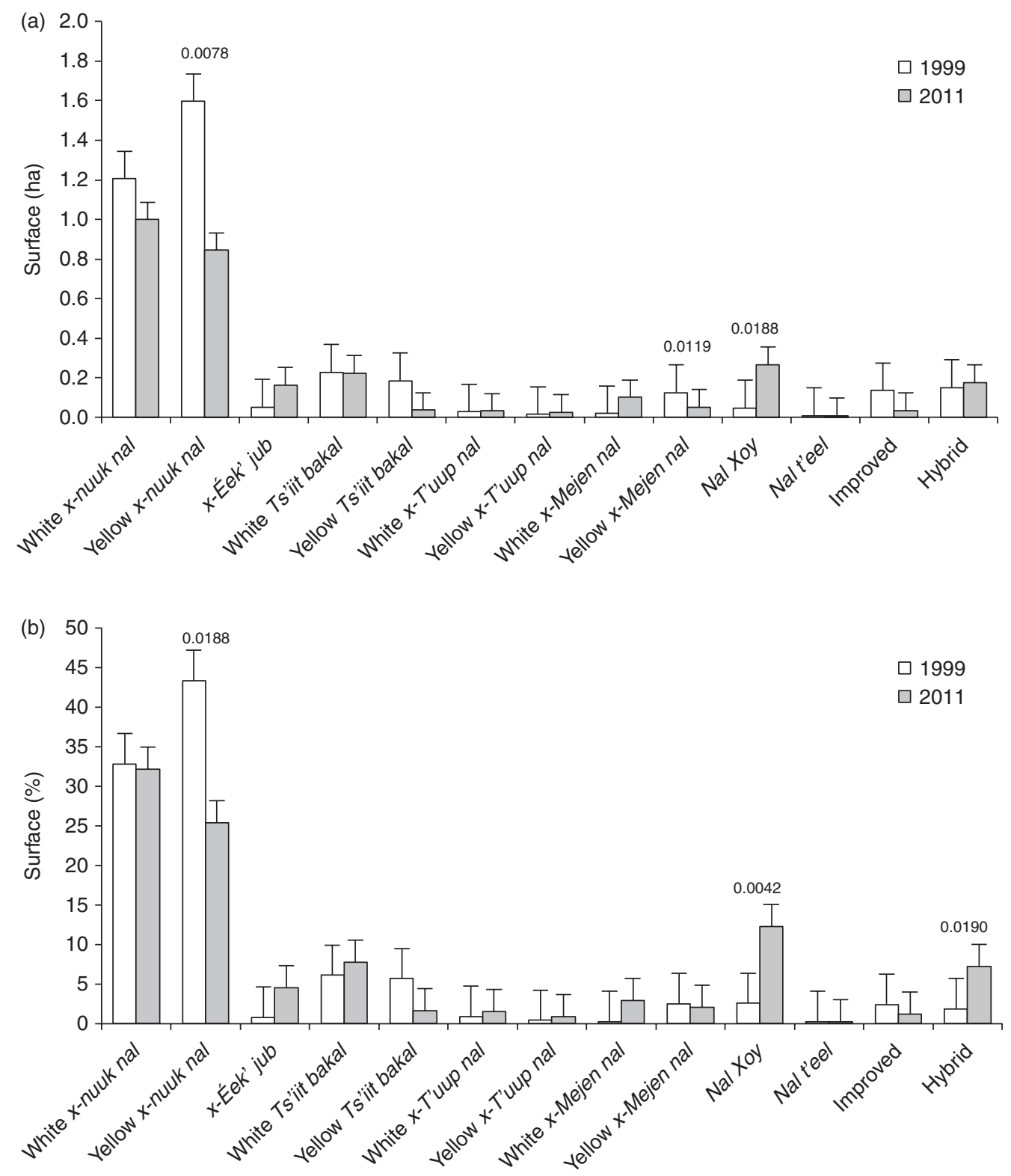

Fig. 2. Cultivated maize varieties in 1999 and 2011. Hectares (a) or proportions (b) of surfaces cultivated with the indicated maize varieties in 1999 and 2011. See online Supplementary materials for detailed values of the graphs.

allocated to traditional varieties paralleled by an increase in the areas devoted to locally adapted improved maize varieties was observed in Yaxcaba milpas. Interestingly, the changes in locally adapted improved maize varieties were mainly linked to a strong increase in Nal Xoy cultivation.

\section{Trend towards shorter-cycle varieties}

We next asked whether the observed changes in cultivated varieties were linked to any trend of varieties with particular traits. We observed a significant reduction in yellow $x$-Nuuk nal, a long-cycle traditional landrace, paralleled by an increase in short- and intermediatecycle locally adapted improved maize varieties and $\mathrm{Nal}$ Xoy in particular. We found a significant decrease in proportions of areas cultivated with long-cycle traditional varieties, namely yellow and white $x$-Nuuk nal, $x$-Éek' jub and yellow and white Ts'it bakal from 1999 $(86.33 \pm 2.89 \%)$ to $2011(71.47 \pm 4.28 \%)(P=0.0078)$. We detected a parallel increase in the proportions of areas cultivated with either traditional (yellow and white $x$-T'unp nal, yellow and white $x$-Mejen nal, 
(a)

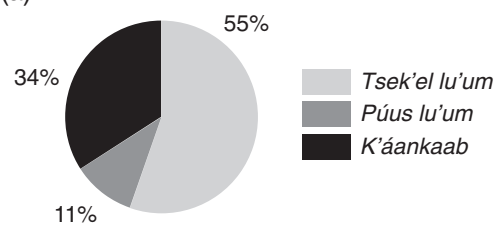

(b)

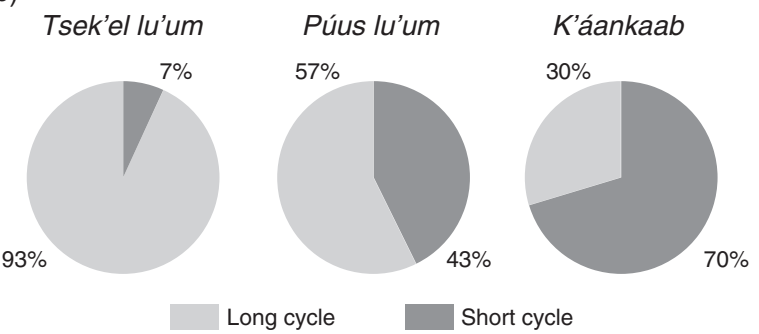

(c)

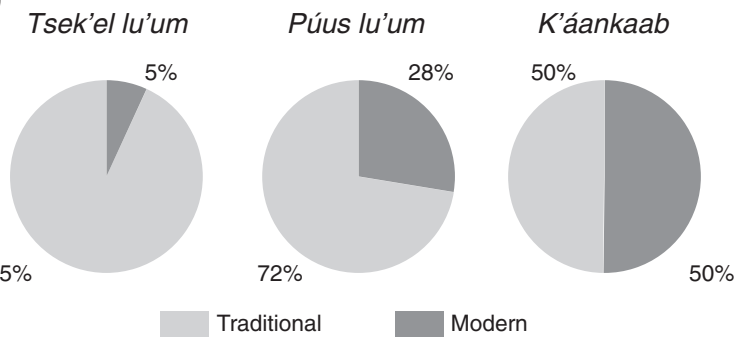

Fig. 3. Distribution of maize varieties depending on soil types. (a) Pie chart representing the proportions of different soil types: Tsek'el lu'um (light grey part), Púus lu'um (dark grey part) and K'áankaab (black part). (b) Pie chart representing the proportions of lands cultivated with long-cycle (dark grey parts) or short-cycle (light grey parts) varieties. (c) Pie chart representing the proportions of lands cultivated with traditional (dark grey part) or modern (light grey part) varieties.

Nal t'eel) or locally adapted improved short-cycle varieties (Nal Xoy, Mejorado, Hibrido) from 1999 $(13.67 \pm 2.89 \%)$ to $2011(28.53 \pm 4.28 \%)(P=0.0078)$.

\section{Agroecological distribution of maize varieties depending on soil types}

Despite a significant increase in the proportions of areas allocated to cultivating short-cycle maize varieties, the great majority of milpa lands are still devoted to longcycle traditional varieties. Results of analysing the agroecological distribution of maize varieties in Yaxcaba according to soil types in 2011 are shown in Fig. 3(a). Yaxcaba lands devoted to maize cultivation are dominated by three main types of soil, which we identify here using both their local (Yucatec Mayan) and scientific taxonomy. Tsek'el lu'um (Lithosol), called pedregoso in Spanish, is a young, extremely stony, shallow, thin soil mainly present in the form of calcareous outcrops, which represented $55.34 \pm 4.70 \%$ of cultivated land in 2011. A second, stony, dark-coloured soil type called Púus lu'um (Redzina) of variable depth, which presents a relatively high organic matter content, represented $10.58 \pm 2.51 \%$ of cultivated areas. Finally, K'áankaab (Cambisol), called kankabal in Spanish, is a deep, welldrained, reddish or reddish-black coloured, fine-grained soil type, and represented $34.09 \pm 4.42 \%$ of maize cultivated areas. We then looked at long- and short-cycle varieties' distribution depending on soil type. The great majority of Tsek'el lu'um under cultivation was allocated to long-cycle varieties; the areas cultivated with shortcycle varieties represented only $6.9 \%$ of these soils (Fig. 3(b)). Interestingly, short-cycle varieties covered $42.7 \%$ of Púus lu'um areas and reached $70.3 \%$ in the case of K'áankaab plots $(P<0.0001$; Fig. 3(b)). We next looked at the proportions of lands cultivated with traditional or modern varieties depending on soil type. Tsek'el lu'um and Púus lu'um lands were mainly cultivated with traditional varieties (95.4 and $72.4 \%$, respectively), while half of the K'áankaab areas (50.2\%) were allocated to the cultivation of modern varieties $(P<0.0001$; Fig. 3(c)). These results reveal great differences in the distribution of maize varieties depending on soil type, with short-cycle and modern varieties being more represented especially on the deeper and fine-grained K'áankaab soils.

\section{Discussion}

In the central part of Yucatan state, where the municipality of Yaxcaba is located, the agricultural system is still largely traditional and centered on milpa cultivation due to extremely stony lands and because of strong community cohesion in continuing to manage ejido lands as common property, with individual farm households having usufruct rights to milpa, beekeeping and other productive activities.

Our results show that more farmers in 2011 failed to satisfy their household consumption needs with their own maize production compared with in 1999, and therefore needed to buy maize from off-farm sources. Accordingly, fewer farmers had sufficient surplus maize production to commercialize for sale in 2011 when compared with in 1999. These observations indicate that maize cultivation in Yaxcaba continues to be mainly aimed at household consumption. Interestingly, farmers who still commercialize their maize production expressed a growing interest in the maize seed trade, considering it a better way to add value to their production and their knowledge of seed selection.

By performing a longitudinal analysis on a farmer population, our study shows that in 2011 the number of 
farmers paying other farmers to work in their milpa increased when compared with 1999. Such a result indicates an increase in household financial resources deployed for growing milpa. Agriculture-related activities such as beekeeping for honey production, already represented in 1999, are an important source of household income but did not increase over time. We can hypothesize that other, not agriculture-related, sources of economic support increased in latter years, with increasing numbers of farmers performing seasonal jobs or migrating for short periods to earn money. In many cases, wage employment and intermittent migration out of Yaxcaba provide a funding system that allows the household to pay other younger farmers for the most laborious activities involved in the process of making milpa. Whether such changes in economic resources for milpa could affect maize varietal diversity maintenance and conservation by farmers needs further investigation.

Even with the increased availability of improved and hybrid seeds over the last 12 years, farmers in Yaxcaba on average plant more than three quarters of their milpa fields to traditional maize varieties, and plant the latter remaining quarter predominately to a locally improved variety Nal Xoy. Collectively, these results demonstrate stability in the average household maize diversity cultivated in Yaxcaba between 1999 and 2011.

Analysis of changes in the proportions of cultivated varieties in Yaxcaba shows that all improved maize varieties are not equivalent. The area of locally adapted improved varieties significantly increased primarily due to the adoption of the Nal Xoy variety, while the nationally released and hybrid varieties did not change significantly in their extent of adoption from 1999 to 2011. Nal Xoy's history and diffusion pattern suggest that this new variety developed by farmers for agricultural households is efficiently adapted to local needs. The title of Rufino Chi Canul's communication (2002) is very eloquent: 'Nalxoy, maize for traditional milpa'. In 1983, upon the introduction of the improved variety named PR-7822 in the village of Xoy, people realized that, although providing good yields, this variety presented some drawbacks in its susceptibility to pest attacks during storage, and in its culinary qualities. To solve these problems the new variety was crossed by farmers in Xoy with a population of Nal t'eel. As Rufino Chi reported, people 'could store in "trojes", maize that could be intercropped with common beans and lima beans, maize that would be easy to degrain by hand, and maize that would be good for 'tortillas, pozole, and other foods' (Chi Canul, 2002, p. 37). Because of the interest that developed for what has thereafter been named Nal XoY variety and with some institutional help, Nal Xoy rapidly spread among farmers all over the Yucatan Peninsula.
Soil taxonomy and land quality affect both the distribution of maize varieties across the landscape and the probability of farmers' adoption of improved varieties (Latournerie et al., 2006; Bellón and Taylor, 1993). Agriculture in the state of Yucatan has been shaped by significant environmental constraints, including the predominance of shallow stony soils, periodic shortfalls of rainfall during the growing season and the risk of major disturbance from cyclones (Duch, 1991). Certain maize varieties are specifically targeted for different soil types based on their agronomic competitiveness (Bellón and Taylor, 1993). The permanence of shifting cultivation systems in extremely stony lands probably plays an important role as well in local varieties' adoption. The management of varieties depending on soil quality can help to explain the low adoption of improved varieties. In Yaxcaba, locally adapted improved maize varieties generally fail to outperform traditional varieties on lowquality soils. Farmers plant inaccessible and stony plots with landraces in order to not be dependent on exogenous factors requiring high monetary investment and best care. In contrast, K'áankaab soils that are easily readily accessible to farm households require relatively high quantities of inputs and more efforts to control for weeds compared with milpa plots managed under longer fallow periods in the 'monte' (woods). Kankabales are the areas where locally adapted improved maize is mainly represented and where a logic prevails of intensified production, with shortened fallow periods (often approaching continuous cultivation) and a high dependency on the use of commercial NPK fertilizer and herbicides (Tuxill, 2005). Farmers consider their traditional maize varieties to be better adapted to the conditions of the ejido outside of the kankabales sites. This study highlights the importance of maize landraces for Yaxcaba farmers in capitalizing on all soils in the ejido, as kankabales represent only about one third of the area available for milpa agriculture in Yaxcaba.

The wide panel of varieties accessed creates a mosaic of traditional and improved maize varieties within and among the Yaxcaba agricultural landscape. Such a mosaic provides the opportunity for continuous gene flow among maize varieties, sustaining the on-going evolution of the crop (Bellón and Brush, 1994; Jarvis and Hodgkin, 1999; Louette and Smale, 2000; Bellón and Risopoulos, 2001). However, management practices employed by farmers for selection of features to be maintained in the next generation may limit gene flow between varieties. Farmers' selection of agro-morphological characteristics may reflect farmers' reactions to new genetic diversity introduction in their crop populations, accepting or promoting desired traits from improved varieties or conserving favourable traits from old ones (Perales et al., 2003b). The cycle of maturation is probably one of the characteristics that 
farmers have modified through selection (Vigouroux et al., 2011). The existence in Yaxcaba of two racial complexes (long cycle and short cycle) can be explained by the need to avoid having maize plants that are flowering or filling out ears when periodic short-term interaestival drought conditions (known locally as la canicula) occur (Tuxill et al., 2010). Environmental factors such as recent changes in rainfall regime or hurricanes may influence farmers' decision-making, potentially leading to changes in two ways. The first is the change in milpa planting months that has moved from May/June to June/July (Canul Ku, 2009). The second is, as observed in this study, a reduction of long-cycle traditional maize varieties paralleled by an increase in short-cycle locally improved varieties. This change may mean that producers are moving these two complexes toward a 'variety balance' as an additional way to ensure production in a context of increased climate uncertainty.

Despite the increased introduction and supply of improved maize varieties in the Yucatan Peninsula over the last 12 years, farmers continue to maintain a substantial amount of traditional maize variety diversity. Accordingly, less than $25 \%$ of maize seeds in Mexico were purchased from formal sectors in 1999 (Ortega Paczka et al., 2000). Farmers choose among a portfolio of maize varieties: traditional, locally improved, nationally improved and hybrid. Over the 12 years of this study, the richness (number of varieties) and their evenness in terms of area planted by Yaxcaba farm households remained the same.

Several previous case studies at the community level in Mexico (Perales et al., 2000; Perales et al., 2005; Latournerie-Moreno et al., 2006; Brush and Perales, 2007; Bellón and Hellin, 2011; Tuxill et al., 2010) and elsewhere (Brush, 2004; Guzman et al., 2005; Bisht et al., 2007; Rana et al., 2007; Jarvis et al., 2008; Bezançon et al., 2009; FAO, 2010; Jackson et al., 2010; Mulumba et al., 2012; Zimmerer, 2013) have demonstrated the persistence of landraces for climatic, ecological, cultural or social reasons. This trend is reaffirmed by the data from Mexico's national effort for maize diversity recollection (CONABIO, 2014). Comparing race richness from this last collection and of historical collections started in the late 1940s, Perales and Golicher, (2014) conclude that maize diversity in Mexico is relatively stable although not evenly distributed within their 11 designated biogeographic regions. In contrast, in a recent study employing matched longitudinal data from the Mexico National Household Survey (ENHRUM), Dyer et al. (2014) argue that the data obtained from case studies, which collectively suggest maize diversity is maintained in Mexico, are overshadowed by a widespread loss of maize diversity at a national scale. Dyer et al. (2014)'s measurements of richness of maize varieties, elaborated from random household interviews in Mexico show a notable drop in richness between 2002 and 2007 of 1.43 to 1.22 varieties at the household level. From these results, Dyer et al. (2014) conclude that previous community-based case studies have failed to find genetic erosion in maize populations due to a preference or bias for atypically high-diversity sites on the part of researchers.

Our research in Yaxcaba addresses one of the principle critiques of previous case studies on maize diversity raised by Dyer et al. (2014, 2015), in that we utilize matched longitudinal data that required following a survey sample of farmers over an extended period of time, in our case 12 years. Although our study area, Yaxcaba, was not included in the ENHRUM national survey sample, our study time period overlaps entirely with that of Dyer et al. (2014). We suspect our conclusions differ predominantly because of the sampling methodology of the ENHRUM survey on which Dyer et al. (2014)'s conclusions are based. The ENHRUM survey strategy was to sample many communities but relatively few households per community, i.e. 68 maize sowing communities were covered (Dyer et al., 2014), but only a total of 606 households sowing maize were interviewed (Dyer and López-Feldman, 2013), resulting in a variable and probably too low number of households sampled in each community covered in the survey. In contrast, the majority of studies measuring the amount of crop genetic diversity held by smallholder farmers in traditional agricultural communities worldwide, and in Mexico in particular, show that the number of varieties captured by surveying a limited number of farmers within a community is generally not representative of the pool of varieties available to farmers at the community level (Jarvis et al., 2008; Bajracharya et al., 2010; Mulumba, 2012; Brush et al., 2015). Our longitudinal survey monitored varieties grown by 61 individual interviewees of the Yaxcaba community in 1999 and 71 in 2011, and we did not find any significant genetic erosion at the community level, even with substantial fluctuation in the relative abundance of some varieties. A second methodological difference with our study is that the ENHRUM survey addressed maize varieties within a very extensive questionnaire that was not focused primarily on maize diversity. It is our opinion that this is not an optimal way to obtain high-quality information on maize diversity. In our study, particular attention was given to gather maximum information about seed lots, seed distribution and seed flows, through specific and repeated questions on each variety, both in local Spanish and Yucatec Maya names. These deep discussions allowed confirmation of the amount and distribution of hybrid maize varieties in the community, a methodology widely used to better understand the number of varieties accessed 
within a community (Louette et al., 1997; Pautasso et al., 2012).

Dyer et al. (2014) warn against the continuing decline in average number of maize varieties per household, focusing on the first decade of the 21st century. In fact, the maize varietal landscape in Mexico began to undergo substantial change much earlier than 2002. Mexico is one of the first countries to have developed hybrid maize varieties (or to introduce them from USA) through the Rockefeller Foundation's programmes in the mid-1940s (Cotter, 2003). Commercial varieties have been spread and tested in a wide range of environments in rural Mexico since 1950. In the USA and France, hybrid maize varieties largely replaced local materials in less than a decade during the 1950s for USA and 1960s for France (Bonneuil and Thomas, 2009). There is no reason to think that farmers in the marginal zones of Mexico waited for 60 years to access and adopt the new seeds when fertilizer, and later herbicides, were integrated widely by farmers in the same zone. The replacement phenomenon was not evenly distributed: in regions of Mexico where farming of new varieties gave a more important commercial advantage, local varieties have been replaced since the 1950s, whereas in regions where landraces displayed a competitive advantage thanks to their local adaptation, today we still find considerable diversity and gene flow. Observations by Dyer et al. in the North and West of Mexico reflect this dynamic in explaining the origins of the current low levels of maize diversity there as well as the low replacement rates indicative of a stabilized situation. However, their argument becomes problematic when arguing that maize diversity has changed significantly between 2002 and 2007 in communities with environmental, social, and linguistic characteristics supporting the maintenance of maize diversity, such as much of the Yucatan Peninsula.

Our longitudinal analysis on a time frame that overlaps with that studied by Dyer et al., found no evidence of genetic erosion in Yaxcaba, a community representative of much of southern and south-east Mexico in terms of maize diversity. In Mexico, as elsewhere in the world, many farmers continue to keep their traditional varieties for pragmatic reasons: as a means for improving agricultural production and productivity in low input conditions; as an insurance to maintain productivity in heterogeneous environments, or under changing climates; for the sustained local consumer demand for diverse food products, and because of the concerns and interests of the farmers and communities themselves who wish to retain control over their production systems (Perales et al., 2003a; Edmeades et al., 2006; Salazar et al., 2007; Giuliani, 2007; Bellón et al., 2009; Bocci and Chable, 2009; Kontoleon et al., 2009; Practical Action,
2011; Thomas et al., 2011; Jarvis et al., 2016). Our findings confirm that in areas with limiting climatic and soil conditions, which constitute a large part of Mexico, farmers have continued to maintain their traditional varieties or the creole varieties that contain the germplasm of their traditional varieties crossed with commercial seed. We note that the first wave of traditional variety replacement has already passed in Mexico. Longitudinal case studies have supplied important insights on farmers' adjustments after this first wave and the roles traditional varieties continue to play in ensuring agricultural production and cultural identity for smallholder farmers in the Yucatan.

\section{Supplementary material}

To view supplementary material for this article, please visit http://dx.doi.org/10.1017/S1479262115000374

\section{Acknowledgements}

The authors thank the Swiss Agency for Development and Cooperation (SDC) for providing financial support to this study, and the International Development Research Centre (IDRC), Canada for funding the 1999 survey. Marianna Fenzi was supported by a PhD scholarship from the Centre Alexandre-Koyré, École des hautes études en sciences sociales (EHESS). The authors thank Dr. Luis Dzib Aguilar for helpful discussions. The 1999 Yaxcaba survey was carried out by Jose Vidal Cob Uicab, Jaime Canul Ku, Luis Burgos May and Teresa Quinones. They also thank them for their data collection, and thank all Yaxcaba farmers for generously sharing their experience and knowledge. They thank Efraim Moo Ake for his crucial help in carrying out the field work.

\section{References}

Anderson E (1946) Maize in Mexico a preliminary survey. Annals of the Missouri Botanical Garden 33: 147-247.

Arias L (1995) La producción milpera actual en Yaxcabá, Yucatán. In: Hernández E, Bello E and Levy S (eds) La milpa en Yucatán. vol. 1. Montecillo, Estado de México: Colegio de Posgraduados, pp. 171-200.

Arias L, Chavez-Servia J, Cob JV, Burgos L and Canul J (2000) Agro-morphological characters and farmers' perceptions : data collection and anaysis. In: Jarvis D, Sthapit B and Sears L (eds) Conserving Agricultural Biodiversity In Situ: A Scientific Basis for Sustainable Agriculture. Rome, Italy: International Plant Genetic Resources Institute, pp. 95-100. 
Arias L, Jarvis D, Williams D, Latournerie L, Márquez F, Castillo F, Ramirez P, Ortega R, Ortiz J, Sauri E, Duch J, Bastarrachea J, Guadarrama M, Cazares E, Interian V, Lope D, Duch T, Canul J and Burgos L (2002) Conservación in situ de la biodiversidad de las variedades locales en la milpa de Yucatán, México. In: Chávez-Servia JL, Tuxill J and Jarvis D (eds) Manejo de la diversidad de los cultivos en los agroecosistemas tradicionales. Rome, Italy: International Plant Genetic Resources Institute, pp. 36-46.

Bajracharya J, Rana RB, Gauchan D, Sthapit BR, Jarvis DI and Witcombe JR (2010) Rice landrace diversity in Nepal. Socio-economic and ecological factors determining rice landrace diversity in three agro-ecozones of Nepal based on farm surveys. Genetic Resources and Crop Evolution 57: 1013-1022.

Bellón MR and Taylor JE (1993) "Folk" soil taxonomy and the partial adoption of new seed varieties. Economic Development and Cultural Change 41: 763-786.

Bellón MR and Brush SB (1994) Keepers of maize in Chiapas, Mexico. Economic Botany 48: 196-209.

Bellón MR and Risopoulos J (2001) Small-scale farmers expand the benefits of improved maize germplasm: a case study from Chiapas, Mexico. World Development 29: 799-811.

Bellón MR and Hellin J (2011) Planting hybrids, keeping landraces: agricultural modernization and tradition among small-scale maize farmers in Chiapas, Mexico. World Development 39: 1434-1443.

Bellón MR, Barrientos-Priego AF, Colunga-GarcíaMarín P, Perales H, Agüero JAR, Serna RR and Zizumbo-Villareal D (2009) Diversidad y conservación de recursos genéticos en plantas cultivadas. Capital natural de México 2: 355-382.

Bezançon G, Pham JL, Deu M, Vigouroux Y, Sagnard F, Mariac C, Kapran I, Mamadou A, Gérard B, Ndjeunga J and Chantereau J (2009) Changes in the diversity and geographic distribution of cultivated millet (Pennisetum glaucum (L.) R. Br.) and sorghum (Sorghum bicolor (L.) Moench) varieties in Niger between 1976 and 2003. Genetic Resources and Crop Evolution 56: 223-236.

Bisht IS, Mehta PS and Bhandari DC (2007) Traditional crop diversity and its conservation on-farm for sustainable agricultural production in Kumaon Himalaya of Uttaranchal state: a case study. Genetic Resources and Crop Evolution 54: 345-357.

Bocci R and Chable V (2009) Peasant seeds in Europe: stakes and prospects. Journal of Agriculture and Environment for International Development 103: 81-93.

Bonneuil C and Thomas F (2009) Gènes, pouvoirs et profits: recherche publique et régimes de production des savoirs de Mendel aux OGM. Éditions Quae, Paris.

Brush S (2004) Farmers' Bounty: Locating Crop Diversity in the Contemporary World. New Haven: Yale University Press.

Brush SB and Perales H R (2007) A maize landscape: ethnicity and agro-biodiversity in Chiapas Mexico. Agriculture, Ecosystems and Environment 121: 211-221.

Brush SB, Bellon MR, Hijmans RJ, Ramirez QO, Perales HR and van Etten J (2015) Assessing maize genetic erosion. Proceedings of the National Academy of Sciences 112: E2.

Canul Ku J (2009) Diversidad genética de poblaciones nativas de maíz y su mantenimiento en el sistema milpa de Yucatán. Texcoco, México: Colegio de Posgraduados.
Chi Canul R (2002) Nalxoy, maize for traditional milpa. In: Chavez-Servia JL, Arias-Reyes LM, Jarvis DI, Tuxill J, Lope-Alzina D and Eyzaguirre C (eds) Managing Crop Diversity in Traditional Agroecosystems, International Plant Genetic Resources Institute, Rome, Italy, p. 37.

CONABIO (2014) Recopilación, generación, actualización y análisis de información acerca de la diversidad genética de maíces y sus parientes silvestres en México. CONABIO website. Available at http://www.biodiversidad.gob.mx/ genes/proyectoMaices.html (Accessed November 2014)

Cotter J (2003) Troubled Harvest: Agronomy and Revolution in Mexico, 1880-2002. Greenwood Publishing Group, Westport, CT.

Duch J (1991) Fisiografia del estado de Yucatan y su relacion con la milpa. Mexico: Universidad Autonoma Chapingo.

Dyer GA and López-Feldman A (2013) Inexplicable or simply unexplained? The management of maize seed in Mexico. PLOS ONE 8: e68320.

Dyer GA, López-Feldman A, Yúnez-Naude A and Taylor JE (2014) Genetic erosion in maize's center of origin. Proceedings of the National Academy of Sciences 111: 14094-14099.

Dyer GA, López-Feldman A, Yúnez-Naude A, Taylor JE and Ross-Ibarra J (2015) Reply to Brush et al.: Wake-up call for crop conservation science. Proceedings of the National Academy of Sciences 112: E2.

Edmeades S, Smale M and Karamura D (2006) Demand for cultivar attributes and the biodiversity of bananas on farm in Uganda. In: Smale M (ed.) Valuing Crop Biodiversity: On-farm Genetic Resources and Economic Change. Wallingford, UK: CABI Publishing, pp. 97-118.

FAO (2010) Second Report on the World's Plant Genetic Resources for Food and Agriculture. Rome, Italy: United National Food and Agricultural Organization (FAO). Available at http://www.fao.org/docrep/013/i1500e/i1500e00. htm (Accessed August 2014)

Fox J and Haight L (2010) Subsidizing inequality: Mexican corn policy since NAFTA, Woodrow Wilson International Center for Scholars, Centro de Investigación y Docencia Económicas, University of California, Santa Cruz.

Frankel OH (1967) Guarding the plant breeder's treasury. New Scientist 35: 538-540.

Frankel OH (1973) Survey of Crop Genetic Resources in their Centres of Origin. Rome: Food and Agriculture Organization of the United Nations (FAO-IBP).

Frankel OH and Bennett E (1970) Genetic Resources in Plants, their Exploration and Conservation. Oxford: Blackwell.

Giuliani A (2007) Developing Markets for Agrobiodiversity. Securing Livelihoods in Dryland Areas. London, UK: Earthscan Research Editions.

Guzman FA, Ayala H, Azurdia C, Duque MC and Vicente MC (2005) AFLP assessment of genetic diversity of Capsicum genetic resources in Guatemala: home gardens as an option for conservation. Crop Science 45: $363-370$.

Harlan JR (1975) Our vanishing genetic resources. Science 188: $617-621$.

Hernandez XE (1985) Maize and man in the greater Southwest. Economic Botany 39: 416-430.

Jackson L, van Noordwijk M, Bengtsson J, Foster W, Lipper L, Pulleman M, Said M, Snaddon J and Vodouhe R (2010) Biodiversity and agricultural sustainability: from assessment to adaptive management. Current Opinion in Environmental Sustainability 2: 80-87. 
Jarvis DI and Hodgkin T (1999) Wild relatives and crop cultivars: detecting natural introgression and farmer selection of new genetic combinations in agroecosystems. Molecular Ecology 8: S159-S173.

Jarvis DI and Campilan DM (2006) Crop Genetic Diversity to Reduce Pests and Diseases On-farm. Participatory Diagnosis Guidelines. Version 1. Bioversity Technical Bulletin. Bioversity International, Rome, Italy.

Jarvis DI, Brown AH, Cuong PH, Collado-Panduro L, Latournerie-Moreno L, Gyawali S, Tanto T, Sawadogo M, Mar I and Sadiki M (2008) A global perspective of the richness and evenness of traditional crop-variety diversity maintained by farming communities. Proceedings of the National Academy Science 105: 5326-5331.

Jarvis DI, Hodgkin T, Sthapit BR, Fadda C and LopezNoriega I (2011) An heuristic framework for identifying multiple ways of supporting the conservation and use of traditional crop varieties within the agricultural production system. Critical Reviews in Plant Sciences 30: $125-176$.

Jarvis DI, Hodgkin T, Brown AHD, Tuxill J, Lopez Noriega I, Smale M and Sthapit B (2016) Crop Genetic Diversity in the Field and on the Farm; Principles and Applications in Research Practices. New Haven, CT: Yale University Press. In press.

Kato A, Mapes C, Mera LM, Serratos JA and Bye RA (2009) Origen y diversificación del maíz: una revisión analítica. DF, México: UNAM, CONABIO.

Kontoleon A, Pascual U and Smale M (2009) Introduction: agrobiodiversity for economic development: what do we know? Agrobiodiversity conservation and economic development. In: Kontoleon A, Pascual U and Smale M (eds) Agrobiodiversity, Environment and Economic Development. UK: Routledge Explorations, pp. 1-24.

Latournerie Moreno L, Tuxill J, Yupit-Moo E, Arias Reyes L, Cristobal-Alejo J and Jarvis DI (2006) Traditional maize storage methods of Mayan farmers in Yucatán, Mexico: implications for seed selection and crop diversity. Biodiversity and Conservation 15: 1771-1795.

Leclerc C and Coppens d'Eeckenbrugge G (2012) Social organization of crop genetic diversity. The $\mathrm{G} \times \mathrm{E} \times \mathrm{S}$ interaction model. Diversity 4: 1-32.

Louette D and Smale M (2000) Farmers' seed selection practices and traditional maize varieties in Cuzalapa, Mexico. Euphytica 113: 25-41.

Louette D, Charrier A and Berthaud J (1997) In situ conservation of maize in Mexico: genetic diversity and maize seed management in a traditional community. Economic Botany 51: $20-38$.

Magurran AE (2003) Measuring Biological Diversity. Oxford, UK: Blackwell.

Mulumba JW, Nankya R, Adokorach J, Kiwuka C, Fadda C, De Santis P and Jarvis D (2012) A risk-minimizing argument for traditional crop varietal diversity use to reduce pest and disease damage in agricultural ecosystems of Uganda. Agriculture, Ecosystems and Environment 157: $70-86$.

Ortega Paczka R (2003) La diversidad de maíz en México. In: Esteva G and Marielle C (eds) Sin maiz no hay pais. México, D.F. CONACUlTA, pp. 123-154.

Ortega Paczka R and Dzib Aguilar L (1992) Recursos genéticos de maíz para la milpa. In: Zizumbo (ed.) La modernización de la milpa en Yucatán: utopia o realidad. Mérida, CICY, pp. $135-145$.
Ortega Pazcka R, Dzib Aguilar L, Arias-Reyes LM, Cob-Vicab V, Canul-Ku J and Burgos LA (2000) Mexico, seed supply systems: data collection and analysis. In: Jarvis D, Sthapit B and Sears L (eds) Conserving Agricultural Biodiversity in situ: A Scientific Basis for Sustainable Agriculture. Rome, Italy: International Plant Genetic Resources Institute, pp. 152-154.

Pautasso M, Aistara G, Barnaud A, Caillon S, Clouvel P, Coomes OT, Delêtre, Demeulenaere E, De Santis P, Döring T, Eloy L, Emperaire L, Garine E, Goldringer I, Jarvis D, Joly HI, Leclerc C, Louafi S, Martin P, Masso F, McGuire S, McKey D, Padoch C, Soleri C, Thomas $M$ and Tramontini S (2012) Seed exchange networks in agrobiodiversity conservation: concepts, methods and challenges. Agronomy for Sustainable Development 33: 151-175.

Perales H and Golicher D (2014) Mapping the diversity of maize races in Mexico. PloS One 9: e114657.

Perales H, Brush SB and Qualset CO (2000) Agronomic and economic competitiveness of maize landraces and in situ conservation in Mexico. Farmers Gene Banks and Crop Breeding: Economic Analyses of Diversity in Wheat, Maize and Rice. The Netherlands: Springer, pp. $109-126$.

Perales RH, Brush SB and Qualset CO (2003a) Landraces of maize in Central Mexico: an altitudinal transect. Economic Botany 57: 7-20.

Perales H, Brush S and Qualset C (2003b) Dynamic management of maize landraces in Central Mexico. Economic Botany 57: 21-34.

Perales HR, Benz BF and Brush SB (2005) Maize diversity and ethnolinguistic diversity in Chiapas, Mexico. Proceedings of the National Academy of Sciences 102: 949-954.

Practical Action (2011) Hunger, Food and Agriculture: Responding to the Ongoing Challenges. Rugby, Warwickshire: The Schumacher Centre for Technology and Development.

Rana RB, Garforth C, Jarvis D and Sthapit B (2007) Influence of socioeconomic and cultural factors in rice varietal diversity management on-farm in Nepal. Agriculture and Human Values 24: 461-472.

Re Cruz A (1996) The Two Milpas of Chan Kom: Scenarios of a Maya Village Life. Albany: State University of New York Press.

Salazar R, Louwaars NP and Visser B (2007) On protecting farmers' new varieties: new approaches to rights on collective innovations in plant genetic resources. World Development 35: 1515-1528.

SIAP (2011) Servicio de información agroalimentaria y pesquera (SIAP), México. Available at http://www.siap.gob.mx/cierrede-la-produccion-agricola-por-cultivo/ (Accessed November 2014)

Thomas M, Dawson JC, Goldringer I and Bonneuil C (2011) Seed exchanges, a key to analyze crop diversity dynamics in farmer-led on-farm conservation. Genetic Resources and Crop Evolution 58: 321-338.

Tuxill J (2005) Agrarian change and crop diversity in Mayan milpas of Yucatan, Mexico: implications for in situ conservation. PhD Thesis, New Haven, CT, Yale University.

Tuxill JD and Nabhan GP (2001) People, Plants, and Protected Areas: A Guide to In situ Management. London: Earthscan.

Tuxill J, Arias Reyes L, Latournerie L, Uicab VC and Jarvis DI (2010) All maize is not equal: maize variety choices 
and Mayan foodways in rural Yucatan, Mexico. In: Staller J and Carrasco M (eds) Pre-Columbian Foodways: Interdisciplinary Approaches to Food, Culture, and Markets in Ancient Mesoamerica. Springer, New York, p. 467-486.

Vigouroux Y, Mariac C, De Mita S, Pham JL, Gérard B, Kapran I, Sagnard F, Deu M, Chantereau J, Ali A, Ndjeunga J, Luong V, Thuillet A, Saïdou A, Bezançon G. (2011) Selection for earlier flowering crop associated with climatic variations in the Sahel. PloS ONE 6: e19563.
Wilkes HG and Wilkes S (1972) The green revolution. Environment: Science and Policy for Sustainable Development 14: 32-39.

Zimmerer KS (1996) Changing Fortunes: Biodiversity and Peasant Livelihood in the Peruvian Andes. Los Angeles, California, USA: University of California Press.

Zimmerer KS (2013) The compatibility of agricultural intensification in a global hotspot of smallholder agrobiodiversity (Bolivia). Proceedings on the National Academy of Sciences 110: 2769-2774. 